\title{
Prevalence of Articular Cartilage Lesions and Surgical Clinical Outcomes in Football (Soccer) Players' Knees: A Systematic Review
}

\author{
Renato Andrade, B.Sc., Sebastiano Vasta, M.D., Rocco Papalia, M.D, Ph.D., \\ Hélder Pereira, M.D., J. Miguel Oliveira, Ph.D., \\ Rui L. Reis, C.Eng., M.Sc., Ph.D., D.Sc., Doc h.c., and João Espregueira-Mendes, M.D., Ph.D.
}

\begin{abstract}
Purpose: To systematize the available scientific literature on the prevalence of articular cartilage and/or osteochondral lesions in football (soccer) players' knees, and overview the surgical procedures and functional outcomes and return to sports. Methods: A comprehensive search using Pubmed, Cochrane Library, SPORTDiscus, and CINAHL databases was carried out until September 30, 2015. All English language studies that assessed the outcomes of a surgical technique for the treatment of articular cartilage lesions in football players' knees, with a minimum follow-up of 12 months, were included. The reference list of the most relevant papers was screened. The main outcomes of interest were the clinical, arthroscopy or imaging primary outcomes and the return to sports rate. The methodological and reporting qualities were assessed according to Coleman methodology score. Results: The search provided 485 titles and abstracts. Five studies were eligible for inclusion (mean Coleman score of 37.2 points), comprising a total of 183 football players with a mean age of 25.7 years. A total of 217 articular cartilage and/or osteochondral lesions were reported, where the medial and lateral femoral condyles were the most common sites of lesion. The surgical procedures investigated were mosaicplasty, microfracture, autologous chondrocyte implantation, and chondral debridement. Conclusions: No definitive conclusion could be made in respect to the best current surgical technique for articular cartilage and osteochondral lesions. Microfracture and mosaicplasty can provide a faster return to competition and faster clinical and functional results, whereas autologous chondrocyte implantation and/or matrix-induced autologous chondrocytes implantation procedures can enhance longstanding clinical and functional results. Level of Evidence: Level IV, systematic review of Level III and IV studies.
\end{abstract}

From the Faculty of Sports, University of Porto (R.A.), Porto, Portugal; Clínica do Dragão, Espregueira-Mendes Sports Centre-FIFA Medical Centre of Excellence (R.A., H.P., J.M.O., J.E-M.), Porto, Portugal; Dom Henrique Research Centre (R.A., H.P., J.E-M.), Porto, Portugal; Orthopaedic and Trauma Department, Campus Biomedico University of Rome (S.V., R.P.), Rome, Italy; Orthopaedic Department, Centro Hospitalar Póvoa de Varzim (H.P.), Vila do Conde, Portugal; 3B's Research Group-Biomaterials, Biodegradables and Biomimetics, University of Minho, Headquarters of the European Institute of Excellence on Tissue Engineering and Regenerative Medicine (H.P., J.M.O., R.L.R., J.E-M.), AvePark, Parque de Ciência e Tecnologia, Zona Industrial da Gandra, Barco, Portugal; ICVS/3B's-PT Government Associate Laboratory (H.P., J.M.O., R.L.R., J.E-M.), Bragal Guimarães, Portugal; and Orthopaedics Department of Minho University (J.E-M.), Minho, Portugal.

The authors report that they have no conflicts of interest in the authorship and publication of this article.

Received November 11, 2015; accepted January 21, 2016.

Address correspondence to João Espregueira-Mendes, M.D., Ph.D., Clínica do Dragão, Estádio do Dragão, Entrada Nascente Norte Piso -3, 4300-415, Porto,Portugal.E-mail: espregueira@dhresearchcentre.com

(C) 2016 by the Arthroscopy Association of North America 0749-8063/151058/\$36.00

http://dx.doi.org/10.1016/j.arthro.2016.01.055
Dootball (soccer) is the most popular sport worldwide. It is played by more than 300 million people. ${ }^{1}$ However, because of the forceful, repetitive mechanical stress, ${ }^{2-5}$ it is associated with a growing incidence of sports-related articular cartilage damage of the knee. ${ }^{6-8}$ Furthermore, the articular cartilage lacks intrinsic spontaneous self-repair capacity. ${ }^{9-12}$ Hence, the functional long-term restoration of the articular surface is a tough challenge for the orthopaedic community.

Articular cartilage (grade III) or osteochondral (grade IV) lesions (Outerbridge score system) appearing because of degenerative or traumatic causes can often lead to complaints in football players. ${ }^{7,13,14}$ Typical symptoms include pain, swelling, catching, and locking. ${ }^{6,15,16}$

Articular cartilage lesions in the knee may be present in asymptomatic athletes, which, if not treated properly, may lead to an early career ending. ${ }^{12,13,17,18}$ These may also be responsible for early onset of knee 
osteoarthritis, ${ }^{17,19-22}$ and often lead to activity-related symptoms, lifestyle modifications, and reduced athletic performance. ${ }^{15,23}$ Articular cartilage lesions are often associated with anterior cruciate ligament (ACL) deficiency, meniscal tears, and lower limb malalignment, which should be investigated and addressed accordingly. ${ }^{2,13,24-30}$ In fact, the treatment of concomitant pathologies can improve the cartilage repair and allow avoiding repeated surgical interventions, which can positively influence the athlete's return to sports. ${ }^{5,31-33}$

The management of articular cartilage lesions is complex and multifactorial. ${ }^{34}$ The ultimate goal pursued is the durable cartilage restoration that can withstand high mechanical demands and reestablishment of normal knee function. Thus, in this scope, full integration of the regenerated cartilage within the surrounding cartilage and underlying bone for restoring the physiological properties of the entire osteochondral unit $^{3,35}$ is the envisioned clinical goal. Nonsurgical treatments include chondroprotective pharmacotherapy, nonsteroidal anti-inflammatory medication, physiotherapy, and hydrotherapy, which are suitable for initial stages. ${ }^{13}$ The rehabilitation program seeks for the player return to competition within the same level without any compensation and prevents the injury recurrence and long-term sequelae. ${ }^{34,36}$

Evidence-based treatment of articular cartilage lesions in sports is mainly based on the size of the chondral lesion and possible bone involvement. ${ }^{37}$ The common surgical treatment includes microfracture and drilling techniques, mosaicplasty and/or osteochondral autograft transplantation (OATS), autologous chondrocytes implantation (ACI) and/or matrix-induced autologous chondrocytes implantation (MACI), and fresh allograft transplantation. However, no consensus on which is the best technique has been reached so far. Despite that, scientific literature reports good or excellent results for most athletes with good return to sports rate. ${ }^{4,5,8,34,38}$

Postoperative return to play at preinjury level represents the most important outcome for the injured football player. ${ }^{5}$ Nonetheless, which surgical technique yields better clinical and functional outcomes and allows a higher rate of returning to sport at preinjury level is still not unanimously established within the orthopaedic community. Hence, we aimed to systematize the available scientific literature according to the prevalence of articular cartilage and/or osteochondral lesions in football players' knees and overview the corresponding surgical procedures' clinical and functional results and respective return to sports rate. It was hypothesized that different surgical procedures would result in different outcomes and return to sports durations and rates.

\section{Methods}

\section{Search Strategy}

The systematic review of the literature was conducted according to the Preferred Reporting Items for Systematic Reviews and Meta-Analyses statement, which aims to improve the standard of reporting of systematic reviews and meta-analyses. ${ }^{39}$ The protocol used was a priori registered at the International Prospective Register of Systematic Reviews (PROSPERO) (http://www. crd.york.ac.uk/prospero/; ID: CRD42015025620).

A comprehensive database search using Pubmed, Cochrane Library, SPORTDiscus, and CINAHL was carried out. We included original articles that assessed the outcomes of surgical techniques for articular cartilage lesions of football players' knees. All searches were performed up to September 30, 2015. Two investigators (R.A., S.V.) performed the search independently, whose both results were confronted to check for overlapping; any disagreement was discussed until consensus was reached. The reference list of the most relevant original studies was scanned for additional studies. The search strategy comprised the Boolean operators (AND; OR) that combined the following search terms: cartilag*; articul*; chondral; knee; soccer; football; injury; lesion; damage; repair; defect; mosaicplasty; OATS; "osteochondral autograft transfer"; ACI; MACI; "autologous chondrocyte implantation"; "matrix-induced autologous chondrocytes implantation"; "cartilage transplantation"; microfracture; drilling; allograft; chondroplasty. An example of the search is depicted in Table 1 .

\section{Study Selection}

All the titles and abstracts obtained from the databases were screened for relevant articles. The potential relevant studies identified were retrieved and the respective full text analyzed for their eligibility according to the following inclusion criteria: (1) assessment of the outcomes of a particular surgical technique for the treatment of articular cartilage or osteochondral lesions; (2) follow-up of, at least, 12 months; (3) inclusion of a cohort of football players; (4) knee joint; and (5) English language studies. The exclusion criteria were as follows: (1) other reviews or meta-analyses; (2) clinical commentaries or expert opinions; (3) single case studies; (4) animal studies or basic science; (5) skeletally immature population; and (6) inclusion of osteoarthritis instead of articular cartilage and/or osteochondral lesions.

\section{Data Collection and Extraction}

The main outcomes of interest were the clinical, arthroscopic or imaging primary outcomes, and the return to sports rate. Hence, after the eligibility criteria screening and the determination of the articles to be 
Table 1. Example of Search Strategy for the PubMed Database

\begin{tabular}{|c|c|c|}
\hline Search & Search Term(s) & Results \\
\hline$\overline{\# 1}$ & cartilag* & 91,436 \\
\hline \#2 & articul* & 127,045 \\
\hline \#3 & chondral & 2,438 \\
\hline$\# 4$ & (\#1 OR \#2 OR \#3) & 185,823 \\
\hline \#5 & knee & 124,306 \\
\hline \#6 & soccer & 6,836 \\
\hline \#7 & football & 7,701 \\
\hline \#8 & (\#6 OR \#7) & 12,670 \\
\hline \#9 & injury & $1,097,641$ \\
\hline \#10 & lesion & 255,505 \\
\hline$\# 11$ & damage & 414,431 \\
\hline \#12 & defect & 162,216 \\
\hline \#13 & repair & 355,783 \\
\hline$\# 14$ & mosaicplasty & 224 \\
\hline \#15 & OATS & 3,762 \\
\hline \#16 & "osteochondral autograft transfer" & 79 \\
\hline \#17 & ACI & 4,030 \\
\hline$\# 18$ & $\begin{array}{l}\text { "autologous chondrocyte } \\
\text { implantation" }\end{array}$ & 696 \\
\hline \#19 & MACI & 231 \\
\hline$\# 20$ & $\begin{array}{l}\text { "matrix-induced autologous } \\
\text { chondrocytes implantation" }\end{array}$ & 61 \\
\hline \#21 & microfracture & 750 \\
\hline \#22 & allograft & 54,414 \\
\hline$\# 23$ & drilling & 5,291 \\
\hline$\# 24$ & chondroplasty & 170 \\
\hline \#25 & "cartilage transplantation" & 341 \\
\hline \#26 & $\begin{array}{l}\text { (\#9 OR \#10 OR \#11 OR \#12 OR \#13 } \\
\text { OR \#14 OR \#15 OR \#16 OR \#17 OR } \\
\# 18 \text { OR \#19 OR \#20 OR \#21 OR \#22 } \\
\text { OR \#23 OR \#24 OR \#25) }\end{array}$ & $2,052,837$ \\
\hline \#27 & (\#4 AND \#5 AND \#8 AND \#26) & 285 \\
\hline
\end{tabular}

included, the studies were analyzed based on: (1) sample demographics, (2) presence and duration of the symptomatology, (3) classification and characterization (number, local, and size) of the defect, (4) study duration and follow-up (period of time), (5) method of diagnosis, (6) techniques used and concomitant procedures, (7) parameters assessed, (8) return to sports rates, and (9) most significant results.

\section{Methodological Quality Assessment}

An accurate assessment of methodological quality of the study plays a key role for the systematization and interpretation of results. Thus, we used the Coleman methodology score ${ }^{40}$ to assess both the methodological and reporting qualities, and the level of evidence was set accordingly. ${ }^{41,42}$ The Coleman methodology score evaluates the individual study's methodological quality according to 10 criteria divided into 2 sections, resulting in a total score between 0 and 100. A score of 100 indicates that the study largely avoids chance, various biases, and confounding factors. ${ }^{40,43}$ If the score is greater than 85 , the study is considered excellent, between 70 and 84 good, from 50 to 69 moderate, and below 50 poor. ${ }^{44}$

\section{Results}

\section{Study Selection}

The database and hand search resulted in 485 titles and abstracts. After duplicate removal, 370 papers were filtered, resulting in 16 full-text papers that were screened for eligibility. After the full-text screening, 5 original studies ${ }^{7,8,13,33,45}$ were eligible for inclusion and further analysis. Search strategy steps can be seen in the Preferred Reporting Items for Systematic Reviews and Meta-Analyses flow chart (Fig 1), and the reasons for exclusion were as follows: case study, ${ }^{46,47}$ Spanish language ${ }^{48}$ skeletally immature, ${ }^{49}$ or did not divide the football players from the overall athletics cohort on the outcomes analysis. $30-55$

\section{Population Characteristics}

Characteristics of the sample population from the 5 included studies are depicted in Table 2, comprising a total of 183 football players (158 male and 25 female) with a mean age of 25.7 years. Overall, most of the football players $(82 \%)$ were playing at professional level $7,8,13,33,45$ and, when reported, they were all symptomatic. Two of the studies did not make any report of players' symptomatology whatsoever. ${ }^{8,13}$

Only 2 studies ${ }^{7,33}$ reported the duration of symptoms and/or the time spent from injury until the surgery was performed. Mithoefer et al. ${ }^{33}$ reported a mean symptomatology of 26 months (range: 3 to 96 months), ranging from 72 to 96 months until the surgery. By its turn, Levy et al. $^{7}$ reported an average of 3 months (range: 6 weeks to 8 months) until the arthroscopy was performed.

The number of previous surgeries and concomitant injuries was also poorly reported across the studies. Mithoefer and Steadman ${ }^{8}$ reported in their cohort 2 concomitant ACL injuries. Kon et al. ${ }^{45}$ listed the 14 surgeries that their cohort had undergone previously to their study. Mithoefer et al. ${ }^{33}$ reported a mean of 2 surgeries on each player (range: 0 to 13) and 16 concomitant injuries (10 ACL deficiency and 6 meniscal tears).

\section{Chondral and/or Osteochondral Defect Characteristics}

Overall, a total of 217 chondral and/or osteochondral defects on the players' knees were reported across the included studies. Figure 2 displays the prevalence figures of the 203 reported defects: medial femoral condyle $(\mathrm{n}=103)$; lateral femoral condyle $(\mathrm{n}=54)$; patella $(\mathrm{n}=17)$; trochlea $(\mathrm{n}=20)$; lateral tibial condyle $(\mathrm{n}=6)$; medial tibial condyle $(\mathrm{n}=0)$; tibia or tibial plateaus $(n=3)$. The defect size averages ranged from 2.0 to $5.7 \mathrm{~cm}^{2}$.

The defect classification showed heterogeneity on the chosen scoring system: Outerbridge ${ }^{13,33}$; Fairbank. ${ }^{13}$ In 


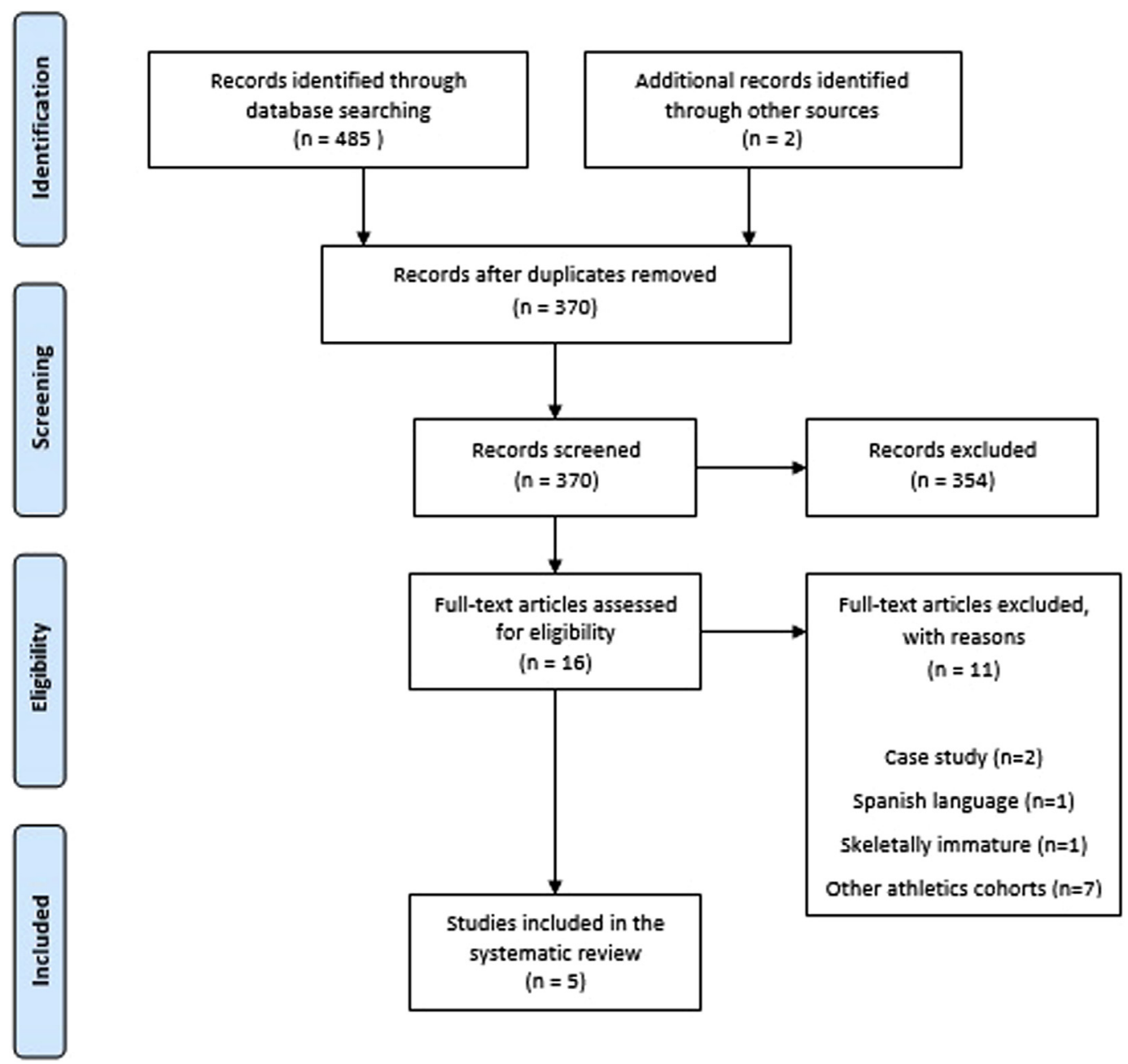

Fig 1. Preferred Reporting Items for Systematic Reviews and Meta-Analyses flow chart for the database search.

addition, 3 studies $^{7,8,45}$ did not define their classification system. However, in 2 of them, 7,45 according to their reports, the defects could be classified as III/IV grade according to the Outerbridge score system. The defects were assessed by arthroscopy, ${ }^{7,33,45}$ magnetic resonance imaging, ${ }^{7,13}$ and radiography ${ }^{13}$ (Table 2).

\section{Surgical Procedures}

In Table 3 are depicted the characteristics of the different surgical procedures used across the studies: mosaicplasty $(\mathrm{n}=61)$; microfracture $(\mathrm{n}=41)$; ACI $(\mathrm{n}=66)$; chondral debridement $(\mathrm{n}=15)$. The studies took from 6 to 16 years to recruit all their football players' sample. The follow-up averages reported within the included original studies were from 1 to 9.6 years.

When reported, the concomitant procedures occurred in $10 \%^{8}$ or $42 \%$ to $69 \%^{13,33,45}$ of the players and the more common were ACL reconstruction $(\mathrm{n}=54)$, meniscectomy $(\mathrm{n}=19)$ and meniscal repair $(\mathrm{n}=4)$, high tibial osteotomy $(\mathrm{n}=9)$, and tibial tubercle osteotomy $(\mathrm{n}=5)$. In addition, 2 studies reported complications in $5 \%^{13}$ and $16 \%^{33}$ players. Another study ${ }^{45}$ stated that no complications had occurred at all.

\section{Time Played After the Cartilage Procedure}

Levy et al. ${ }^{7}$ reported that $26 \%$ of the football players only played for a mean of 1.6 years after the chondral debridement. In the Kon et al. ${ }^{45}$ study, the follow-up was 2 years; therefore, the maximum durability observed was the study's endpoint. Mithoefer and Steadman ${ }^{8}$ reported that the players who returned to professional soccer continued playing an average of 5 years (range: 1 to 13 years), and, the Mithoefer et al. ${ }^{33}$ study reported that $87 \%$ of the footballers kept playing for an average of $52 \pm 7.8$ months. Pánics et al. ${ }^{13}$ did not report on that issue.

\section{Outcomes of Interest}

High heterogeneity was found across the studies concerning outcome assessment parameters. 7,8,13,33,45 In this sense, each study used a different set of scores and/or parameters to assess its outcomes. The only recurrent scores were the International Cartilage Repair Society (ICRS) score, ${ }^{13,45}$ Tegner score, ${ }^{33,45}$ and the Brittberg clinical grading instrument. ${ }^{7,33}$

The studies reported good to excellent results for all surgical techniques. ${ }^{7,8,13,33,45}$ Nonetheless, uneven 
Table 2. Population and Articular Cartilage and/or Osteochondral Lesion Characteristics

\begin{tabular}{|c|c|c|c|c|c|c|c|}
\hline First Author (yr) & $\begin{array}{c}\text { Population } \\
\text { Characteristics }\end{array}$ & Defect Location & $\begin{array}{l}\text { Defect Size Mean } \\
\text { (range) and Number }\end{array}$ & Defect Classification & Method of Diagnosis & CMS & Level of Evidence \\
\hline Pánics et al. $(2012)^{13}$ & $\begin{array}{l}\mathrm{n}=61 \\
55 \mathrm{M} / 6 \mathrm{~F} \\
25.3 \mathrm{yr}\end{array}$ & $\begin{array}{l}\text { MFC }=38 \\
\text { LFC }=15 \\
\text { LTC }=3 \\
\text { MTC }=0 \\
\text { Patella }=4 \\
\text { Trochlea }=1\end{array}$ & $\begin{array}{l}2.4 \mathrm{~cm}^{2}\left(1.0-5.0 \mathrm{~cm}^{2}\right) \\
\mathrm{n}=61\end{array}$ & $\begin{array}{l}\text { Outerbridge } \\
\text { ( } 67 \% \text { of III/IV; } 33 \% \text { of shallow } \\
\quad \text { osteochondral lesions) } \\
\text { Baseline Fairbank } \\
\text { (28\% of } / / \mathrm{II}) \\
\text { Final Fairbank } \\
(35 \% \text { of } \mathrm{I} / \mathrm{II} / \mathrm{III})\end{array}$ & $\begin{array}{l}\text { MRI } \\
\text { Radiography }\end{array}$ & 59 & IV \\
\hline $\begin{array}{l}\text { Mithoefer and Steadman } \\
(2012)^{8}\end{array}$ & $\begin{array}{l}\mathrm{n}=21 \\
21 \mathrm{M} / 0 \mathrm{~F} \\
27 \mathrm{yr}\end{array}$ & $\begin{array}{l}\text { MFC }=7 \\
\text { LFC }=14 \\
\text { LTC }=3 \\
\text { MTC }=0 \\
\text { Patella }=3 \\
\text { Trochlea }=3\end{array}$ & $\begin{array}{l}\mathrm{NR} \\
\mathrm{n}=30\end{array}$ & $\mathrm{NR}$ & NR & 17 & IV \\
\hline Kon et al. $(2011)^{45}$ & $\begin{array}{l}\mathrm{n}=41 \\
41 \mathrm{M} / 0 \mathrm{~F} \\
25.1 \mathrm{yr}\end{array}$ & $\begin{array}{l}\text { MFC }=27 \\
\text { LFC }=10 \\
\text { LTC }=0 \\
\text { MTC }=0 \\
\text { Patella }=0 \\
\text { Trochlea }=7\end{array}$ & $\begin{array}{l}2.0 \mathrm{~cm}^{2} \\
\mathrm{n}=44\end{array}$ & $\begin{array}{l}100 \% \text { of grade III/IV chondral lesions } \\
\text { of the femoral condyles or trochlea } \\
>1 \mathrm{~cm}^{2}\end{array}$ & Arthroscopy & 78 & II \\
\hline Mithoefer et al. $(2005)^{33}$ & $\begin{array}{l}\mathrm{n}=45 \\
32 \mathrm{M} / 13 \mathrm{~F} \\
26 \mathrm{yr}\end{array}$ & $\begin{array}{l}\mathrm{MFC}=22 \\
\mathrm{LFC}=10 \\
\mathrm{TC}=2 \\
\text { Patella }=5 \\
\text { Trochlea }=6\end{array}$ & $\begin{array}{l}5.7 \mathrm{~cm}^{2} \\
\mathrm{n}=45\end{array}$ & $\begin{array}{l}\text { Outerbridge } \\
\text { (100\% of type IV articular cartilage } \\
\text { lesions) }\end{array}$ & Arthroscopy & 46 & IV \\
\hline Levy et al. $(1996)^{7}$ & $\begin{array}{l}\mathrm{n}=15 \\
9 \mathrm{M} / 6 \mathrm{~F} \\
\mathrm{NR}\end{array}$ & $\begin{array}{l}\text { MFC =9 } \\
\mathrm{LFC}=5 \\
\mathrm{TP}=1 \\
\text { Patella }=5 \\
\text { Trochlea }=3\end{array}$ & $\begin{array}{l}4.2 \mathrm{~cm}^{2}\left(0.6-7.0 \mathrm{~cm}^{2}\right) \\
\mathrm{n}=23\end{array}$ & $100 \%$ of full thickness chondral lesions & $\begin{array}{l}\text { MRI } \\
\text { Arthroscopy }\end{array}$ & 36 & IV \\
\hline
\end{tabular}
medial tibial condyle; NR, none reported; TC, tibial condyles; TP, tibial plateaus. 


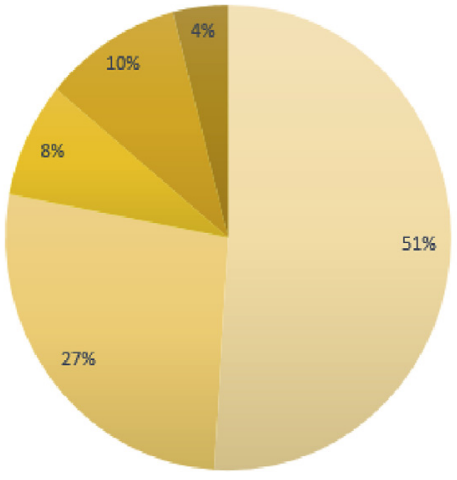

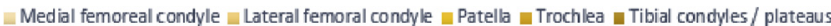

Fig 2. Prevalence of the articular cartilage and/or osteochondral lesions (\%).

rates of return to play were found when comparing the studies (Table 4). Microfracture and chondral debridement were the ones that allowed a higher rate of return to sport within the preinjury level. ${ }^{7,8,45}$ Mosaicplasty, microfracture, and chondral debridement provided a faster return to competition. . $8,13,45^{-1}$

\section{Methodological Quality}

The Coleman methodology score calculated for each study is shown in Table 2. A more detailed scoring for each single parameter can be seen in Table 5 . The mean score was $37.2 \pm 13.3$ points, and the studies were classified as Level $\mathrm{II}^{45}$ or IV. 7,8,13,33

Several major issues were found on the description of postoperative rehabilitation and patient compliance, outcome criteria reporting and quality, procedures of the outcome assessment, and the description of the subject selection process. The type of study was also poorly scored once the most studies were case series.

\section{Discussion}

The main findings of our systematic review were that all surgical techniques showed good to excellent results in the most players, according to the Brittberg, ${ }^{7,33}$ International Knee Documentation Committee, ${ }^{45}$ and the ICRS $^{13}$ scoring systems. Furthermore, the football players could successfully return to sports after a microfracture, ${ }^{8,45}$ mosaicplasty, ${ }^{13} \mathrm{ACI},{ }^{45}$ or chondral debridement. $^{7}$ These results are encouraging because, when dealing with professional football players, returning as fast and as safe as possible to competition within the preinjury level, and without long-term sequelae, represents the ultimate goal.

The most studies included osteochondral lesions (grade IV), and the most common location was the medial femoral condyle, followed by the lateral one. These findings are in line with those ones reported by Flanigan et al., ${ }^{6}$ who reported greater prevalence on the athletes' femoral condyles $(35 \%, 24 \%$ of which were on the medial femoral condyle and $11 \%$ on the lateral femoral condyle), patellofemoral joint (i.e., trochlea and patella; 37\%), and in tibial plateaus (25\%). Although they found higher prevalence of patellofemoral defects when compared with our study, these defects were mainly from professional basketball players. $^{56,57}$ The defect size varied considerably across the included original studies; therefore, no conclusions on this parameter can be made so far. Still, a defect size $<2 \mathrm{~cm}^{2}$ has been reported to yield higher rate of return to high-impact competition after microfracture and mosaicplasty procedures. ${ }^{54,58}$

A total of 101 concomitant procedures were performed, corresponding to more than a half of the overall study population. The ACL reconstruction and partial meniscectomy were the 2 most common procedures. Harris et al. ${ }^{38}$ systematically reviewed the outcomes of several articular cartilage surgical techniques in an athletic population and found similar results concerning the concomitant procedures. Their most common concomitant procedures were the ACL reconstruction $(14 \%)$, partial meniscectomy $(11 \%)$, and meniscal repair $(2 \%)$. Knee concomitant procedures have been recognized to yield a favorable return to competition. ${ }^{33,58,59}$ Few complications have been reported; however, it was already expected because of the limited invasiveness of some of the articular cartilage repair surgical procedures. ${ }^{5}$ The number of previous surgeries was poorly reported across the studies. Only 2 studies $^{33,45}$ reported this parameter. This information is important for the interpretation of the surgical techniques' results once previous surgical interventions may delay the return to competition within the same level, ${ }^{49,54}$ or even punish the success rate of the secondary articular cartilage procedures. $^{60}$

The time from injury until surgery was reported in only 2 studies, ${ }^{7,33}$ and beyond that, the reported periods were very divergent ( 1.5 to 8 months $^{7} v 3$ to 96 months $^{33}$ ). This information would further help clinicians evaluate the results and possible confounders. It has been shown that when the cartilage repair is performed within the following 12 months from injury, it enables an improved repair of the cartilage morphology and a reduced risk of early onset of osteoarthritis. $5,8,12,32,33,49,59$ A fivefold enhancement for returning to sports rate is observed when microfracture is applied and a threefold for ACI procedures. ${ }^{32,33,49,54}$

Concerning the outcome assessment parameters across the included studies, high heterogeneity was found, inclusively in the surgical outcomes scoring systems. Therefore, some caution should be taken when comparing the results from the different studies. Still, the 5 included studies showed similar results, reporting good to excellent results for mosaicplasty, ${ }^{13}$ microfracture, ${ }^{45} \mathrm{ACI}^{33,45}$ and chondral debridement. ${ }^{7}$ 
Table 3. Surgical Procedure Details and Outcome Assessment

\begin{tabular}{|c|c|c|c|c|c|c|c|}
\hline First Author (yr) & $\begin{array}{l}\text { Surgical } \\
\text { Technique }\end{array}$ & Concomitant Procedures? & $\begin{array}{l}\text { Duration } \\
\quad \text { and } \\
\text { Follow-up }\end{array}$ & $\begin{array}{c}\text { Outcome } \\
\text { Assessment }\end{array}$ & Return to Sports & Results & Complications \\
\hline $\begin{array}{l}\text { Pánics et al. } \\
(2012)^{13}\end{array}$ & $\begin{array}{l}\text { Mosaicplasty } \\
\quad(\mathrm{n}=61)\end{array}$ & $\begin{array}{l}\text { Yes, in } 69 \% \text {. } \\
\text { HTO }(\mathrm{n}=6), \text { ACLR } \\
(\mathrm{n}=28), \text { meniscectomy } \\
(\mathrm{n}=6), \text { lateral } \\
\text { retinacular release } \\
(\mathrm{n}=2), \text { and FP } \\
\text { realignment procedure } \\
(\mathrm{n}=1)\end{array}$ & $\begin{array}{l}16 \mathrm{yr} \\
9.6 \mathrm{yr}\end{array}$ & $\begin{array}{l}\text { Modified HSS score, } \\
\text { Lysholm score, modified } \\
\text { Cincinnati score, ICRS } \\
\text { score, skill level, Bandi } \\
\text { scoring system }\end{array}$ & $\begin{array}{l}87 \% \\
67 \% \text { same level } \\
4.5 \mathrm{mo}(3.5-6.1 \mathrm{mo})\end{array}$ & $\begin{array}{l}\text { Good to excellent outcome } \\
\text { occurred in FC }(90 \%), \\
\text { TC }(54 \%) \text {, and PT }(73 \%) \\
\text { Increase on modified HSS } \\
\text { score }(68-90 \text { points, } \\
P<.05) \text {, Lysholm score } \\
\text { (66-93 points, } P<.05) \text {, } \\
\text { modified Cincinnati } \\
\text { score }(59-89 \text { points, } \\
P<.05), \text { and ICRS score } \\
(65 \%-89 \%, P<.05)\end{array}$ & $\begin{array}{l}\text { Postoperative } \\
\text { hemarthrosis } \\
\text { and PF complaints } \\
(5 \%)\end{array}$ \\
\hline $\begin{array}{l}\text { Mithoefer and } \\
\text { Steadman } \\
(2012)^{8}\end{array}$ & $\begin{array}{l}\text { Microfracture } \\
\quad(\mathrm{n}=21)\end{array}$ & $\begin{array}{l}\text { Yes, in } 10 \% \\
\text { ACLR }(\mathrm{n}=2)\end{array}$ & $\begin{array}{l}13 \mathrm{yr} \\
\mathrm{NR}\end{array}$ & $\begin{array}{l}\text { Ability to return and keep } \\
\text { playing }\end{array}$ & $\begin{array}{l}95 \% \\
95 \% \text { same level } \\
\text { NR }\end{array}$ & $\begin{array}{l}\text { Continued to play for an } \\
\text { average of } 5 \mathrm{yr}(1-13 \mathrm{yr})\end{array}$ & NR \\
\hline Kon et al. $(2011)^{45}$ & $\begin{array}{l}\text { Second-generation } \\
\text { ACI }(\mathrm{n}=21) \\
\text { Microfracture } \\
(\mathrm{n}=20)\end{array}$ & $\begin{array}{l}\text { Yes, in } 54 \% \\
\text { ACLR }(\mathrm{n}=14), \text { MCLR } \\
(\mathrm{n}=1), \text { tibial osteotomy } \\
(\mathrm{n}=1), \text { loose body } \\
\text { removal }(\mathrm{n}=1) \\
\text { calcification removal } \\
(\mathrm{n}=2), \text { meniscectomy } \\
(\mathrm{n}=13) \text {, meniscal repair } \\
(\mathrm{n}=2) \text {, and patellar } \\
\text { debridement }(\mathrm{n}=2)\end{array}$ & $\begin{array}{l}6 \mathrm{yr} \\
7.5 \mathrm{yr}\end{array}$ & $\begin{array}{l}\text { ICRS score, IKDC form, } \\
\text { knee functional status, } \\
\text { EQ-VAS score, Tegner } \\
\text { score; time to recover }\end{array}$ & $\begin{array}{l}86 \% \vee 80 \% \\
67 \% \vee 75 \% \text { same } \\
\text { level } \\
12.5 \text { mo } \vee 8 \text { mo }\end{array}$ & $\begin{array}{l}\text { Better results toward ACI } \\
\text { group for IKDC }(P= \\
.005) \text { and EQ-VAS } \\
(P=.035) \text { at follow-up } \\
\text { Microfracture allows a } \\
\text { faster recovery but } \\
\text { deteriorates over time }\end{array}$ & None \\
\hline $\begin{array}{l}\text { Mithoefer et al. } \\
(2005)^{33}\end{array}$ & ACI $(n=45)$ & $\begin{array}{l}\text { Yes, in } 42 \% \\
\text { ACLR }(\mathrm{n}=10), \text { meniscal } \\
\text { repair }(\mathrm{n}=2), \text { TTO } \\
(\mathrm{n}=5), \operatorname{HTO}(\mathrm{n}=3)\end{array}$ & $\begin{array}{l}12 \mathrm{yr} \\
3.4 \mathrm{yr}\end{array}$ & $\begin{array}{l}\text { Tegner score, Brittberg } \\
\text { clinical grading } \\
\text { instrument, functional } \\
\text { outcome rating }\end{array}$ & $\begin{array}{l}33 \% \\
27 \% \text { same level } \\
18.1 \mathrm{mo}(12-24 \mathrm{mo})\end{array}$ & $\begin{array}{l}\text { Good to excellent results } \\
(72 \%) \text { and increased } \\
\text { Tegner scores }(85 \%)\end{array}$ & $16 \%$ \\
\hline Levy et al. $(1996)^{7}$ & $\begin{array}{l}\text { Chondral } \\
\text { Debridement } \\
(\mathrm{n}=15)\end{array}$ & $\mathrm{NR}$ & $\begin{array}{l}\mathrm{NR} \\
1 \mathrm{yr}\end{array}$ & $\begin{array}{l}\text { Brittberg clinical grading } \\
\text { instrument }\end{array}$ & $\begin{array}{l}100 \% \\
100 \% \text { same level } \\
2.7 \mathrm{mo}\end{array}$ & $\begin{array}{l}6 \text { excellent }(40 \%) \text { and } 9 \\
\text { good }(60 \%) \text { at } 1 \text { yr of } \\
\text { follow-up }\end{array}$ & NR \\
\hline
\end{tabular}

ACI, autologous chondrocyte implantation; ACLR, anterior cruciate ligament reconstruction; EQ-VAS, EuroQoL visual analogue scales; FC, femoral condylar; HTO, high tibial osteotomy; HSS, hospital for special surgery; ICRS, International Cartilage Repair Society; IKDC, International Knee Doct
none reported; PF, patellofemoral; PT, patellotrochlear; TC, tibial condylar; TTO, tibial tubercle osteotomy. 
Table 4. Return to Sports by the Surgical Technique

\begin{tabular}{lccl}
\hline \multicolumn{1}{c}{ Surgical Technique } & RTS, \% & Same Level, \% & Time to RTS \\
\hline Microfracture 8,45 & $80-95$ & $75-95$ & $8 \mathrm{mo}$ \\
Mosaicplasty $^{13}$ & 87 & 67 & $4.5 \mathrm{mo}$ \\
$\mathrm{ACI}^{33,45}$ & $33-86$ & $27-67$ & $12.5-18.1 \mathrm{mo}$ \\
Chondral debridment $^{7}$ & 100 & 100 & $2.7 \mathrm{mo}$ \\
\hline
\end{tabular}

ACI, autologous chondrocyte implantation; RTS, return to sports.

Interestingly, the chondral debridement technique alone resulted in good to excellent results. However, $27 \%$ of the players developed other chondral lesions ( $50 \%$ on different sites). It is noteworthy that arthroscopic debridement made by Levy et al. ${ }^{7}$ allowed treating the player's symptoms while the underlying problem was allowed to progress. Still, caution must be taken when comparing the results from different studies due to the different outcome scores used. Good to excellent results may not resemble the same clinical implications, that is, similar structural and functional results. In this sense, some outcomes are based on structural imaging evaluation (ICRS). ${ }^{61}$ Others are related to the assessment of the knee's functionality and symptoms and signs profile (Brittberg ${ }^{62}$ and International Knee Documentation Committee ${ }^{63}$ ).

Given the high financial nature of football, social media impact, stakeholder involvement, and high pressure imposed by the football club directors and investors, the health care professionals are often exposed to higher responsibilities and need to proceed with their clinical judgment under great scrutiny. This may, in some cases, modulate their decisions. Therefore, surgeons must take into account important factors that could influence the return to competition, such as age, level of completion, time into the season, and career status.

All the techniques yielded good rate of return to competition $(80 \%$ till $100 \%)$. One study ${ }^{33}$ reported only a $33 \%$ of return to sports after ACI, although the most players who did not return to sports played recreationally. In fact, only 2 professional footballers did not return to play, whereas 26 of the 31 recreational players did not return, resulting in an overall low return to sports rate.

The chondral debridement and microfracture were the surgical techniques that allowed a higher percentage of returning within the same competitive level. ${ }^{7,8,45}$ In the same line, the chondral debridement (2.7 months), ${ }^{7}$ mosaicplasty (4.5 months), ${ }^{13}$ and microfracture (8 months $)^{45}$ allowed a faster return to competition. The chondral debridement may have allowed the players to return to competition sooner and postponed other more complex surgical procedures. Again, caution should be taken when considering the return to sport rates because the definition of returning to competition diverges within the included studies. In this sense, Levy et al. ${ }^{7}$ considered a successful return to sports when the player could return to pain-free during running, cutting, pivoting, and jumping. While Mithoefer et al. $^{33}$ considered the ability to return to soccer even if not at the previous level, Pánics et al. ${ }^{13}$ took into account only the players who returned to the preinjury level and Kon et al. $^{45}$ evaluated the return to competition based on the Tegner score in relation to the preoperative and preinjury levels. On the other hand, Mithoefer and Steadman, ${ }^{8}$ in their case series, did not report any definition whatsoever.

The articular cartilage repair should provide a longstanding structural repair, which should tolerate the high impact loads imposed to the football players. ${ }^{36}$ In this line, Kon et al. ${ }^{45}$ state that although microfracture allows faster recovery but with clinical deterioration over time, the ACI approach provides delayed return to sports, however with better and more durable clinical results. Bekkers et al. ${ }^{36}$ proposed that if the football player is competing while the articular cartilage repair is needed, a surgical debridement of the focal lesion may be performed, combined with a biopsy procedure for a possible off-season ACI procedure, allowing reduced playing time loss during the season. Because of the young age of these players, when in the presence of full-thickness focal chondral defects $\left(<4 \mathrm{~cm}^{2}\right)$ or osteochondral defects, the mosaicplasty procedure is a good option as a revision procedure for a previously failed microfracture or ACI. ${ }^{2}$ The graft can be effectively taken from the upper tibiofibular joint without any donor zone morbidity. ${ }^{64}$ When considering the durability of the articular cartilage repair procedures, high heterogeneity was found, mostly due to the different follow-up periods reported by the included studies.

Notwithstanding, these techniques have some advantages and disadvantages. Although microfracture can be performed with minimum invasiveness, it takes

Table 5. Methodological Quality According to the Coleman Methodology Score

\begin{tabular}{lrl}
\hline \multicolumn{1}{c}{ Coleman Methodology Score } & Mean (SD) & Range \\
\hline Part A & $5.6(3.8)$ & $0-10$ \\
Study size (10) & $3.4(2.3)$ & $0-5$ \\
Mean duration follow-up (5) & $10(0)$ & 10 \\
No. of treatment procedures (10) & $6(5.5)$ & $0-10$ \\
Type of study (15) & $4(2.2)$ & $0-5$ \\
Diagnostic certainty (5) & $4.2(1.1)$ & $3-5$ \\
Description of surgical procedure (5) & $4(5.5)$ & $0-10$ \\
Rehabilitation \& compliance (10) & & \\
Part B & $5.6(4.3)$ & $0-10$ \\
Outcome criteria (10) & $3.4(5.0)$ & $0-11$ \\
Outcome assessment (15) & $1(2.2)$ & $0-5$ \\
Selection process (15) & $37.2(13.3)$ & $17-52$ \\
Total part A (60) & $10(10.8)$ & $0-26$ \\
Total part B (40) & $47.2(23.1)$ & $17-78$ \\
Total score (100) & & \\
\hline SD, standard deviation &
\end{tabular}

SD, standard deviation. 
a longer period of non-weight-bearing as compared with simple debridement and it lacks fibrocartilage durability. ${ }^{65,66}$ Mosaicplasty provides a faster incorporation of the autologous bone and an instant functional hyaline articular cartilage surface. Nevertheless, it may be restricted by the defect size, donor site morbidity, and fibrocartilage filling between the osteochondral plugs. ${ }^{67,68}$ Despite the ACI longstanding durability, 5,36,45 this procedure implies a higher articular invasiveness, longer time for the defect filling, and higher rate of osteotomy. ${ }^{69}$

Accelerated, goal-based, progression criteria, sportspecific rehabilitation programs can enhance the rate and time to return to play without compromising the graft integrity and the clinical outcomes at mediumterm follow-up. ${ }^{70,71}$ In this sense, several clinical algorithms have been developed. , 36,37,72-74 $^{\text {The secondary }}$ prevention, and management and progression of comorbidities such as osteoarthritis are the milestones to pursuit after the rehabilitation process. ${ }^{1}$

The included original studies showed a low methodological quality according to the Coleman methodology score matched with the low evidence level (1 study Level $\mathrm{II}^{45}$ and 4 studies Level $\mathrm{IV}^{7,8,13,33}$ ), which was in line with the findings of Jakobsen et al. ${ }^{43}$ The most studies were case series, maybe due to the scarce access to a professional football players cohort, opting very often for a longer period of recruitment and not including a control group (due mostly to ethical issues). Future studies should follow the ICRS recommendations $^{75}$ and take into account the limitations found in the previous studies. Thus, they should provide a more comprehensive description of the postoperative rehabilitation and patient compliance, outcome criteria assessment, and subject selection process.

The good clinical outcomes reported, namely excellent return to sport rates within the same level, are encouraging once articular cartilage lesions often occur in the football players leading to reduced sports performance and even to the career ending. It was emphasized that when facing a football player, the surgeon must base his or her judgment on several biological factors, as also the ones inherent with the high demands of the football profession.

\section{Limitations}

The limitations inherent to this review are those arising from the included studies, namely, the lack of prospective data once they were manly retrospective, and the relatively small samples from the case series of the sport-specific population (professional football players). The lack of standardization on the articular cartilage and/or osteochondral lesion classification, non-reported player's individual information (such as body mass index, career status, and level of competition), and the scarce medical history reporting (duration of symptoms, time from injury until surgery, number of previous operations, and concomitant injuries) are issues that may influence the surgical and clinical outcomes. These should be addressed in future studies to avoid the performance bias. The definition of return to sports varied across the studies, which could have biased the comparison between them. Moreover, confounders such as contract negotiations, and competition level may also determine if a player returns to play sooner and lead to bias in the analysis of time to returning to sports. There was also high heterogeneity on the outcome reporting, which precluded the quantitative analysis of the results (meta-analysis) and a more direct and accurate comparison between the studies. A considerable number of studies ${ }^{3,50-55}$ that included football players along with other athletes did not divide them on the outcomes assessment that precluded the separate analysis and led to the exclusion of these studies from our systematic review. To achieve high-level scientific conclusions, more prospective investigation is needed with larger cohort samples of football players, with a more detailed description of the cohort and defect characteristics, as also the rehabilitation programs and the concomitant procedures.

\section{Conclusions}

This study showed that no definitive conclusion could be made in respect to the best surgical technique for articular cartilage and osteochondral lesions. Microfracture and mosaicplasty can provide a faster return to competition and faster clinical and functional results, whereas ACI and/or MACI procedures can enhance longstanding clinical and functional results.

\section{References}

1. Mithoefer K, Peterson L, Saris D, Mandelbaum B, Dvorák J. Special issue on articular cartilage injury in the football (soccer) player. Cartilage 2012;3:4S-5S.

2. Gomoll A, Filardo G, De Girolamo L, et al. Surgical treatment for early osteoarthritis. Part I: Cartilage repair procedures. Knee Surg Sports Traumatol Arthrosc 2012;20: 450-466.

3. Krych AJ, Robertson CM, Williams RJ. Return to athletic activity after osteochondral allograft transplantation in the knee. Am J Sports Med 2012;40:1053-1059.

4. Mithoefer K, Della Villa S. Return to sports after articular cartilage repair in the football (soccer) player. Cartilage 2012;3:57S-62S.

5. Mithoefer K, Hambly K, Della Villa S, Silvers H, Mandelbaum BR. Return to sports participation after articular cartilage repair in the knee scientific evidence. Am J Sports Med 2009;37:167S-176S.

6. Flanigan DC, Harris JD, Trinh TQ, Siston RA, Brophy RH. Prevalence of chondral defects in athletes' knees: A systematic review. Med Sci Sports Exerc 2010;42:1795-1801. 
7. Levy AS, Lohnes J, Sculley S, LeCroy M, Garrett W. Chondral delamination of the knee in soccer players. Am J Sports Med 1996;24:634-639.

8. Mithoefer K, Steadman RJ. Microfracture in football (soccer) players. A case series of professional athletes and systematic review. Cartilage 2012;3:18S-24S.

9. Buckwalter JA. Articular cartilage: Injuries and potential for healing. J Orthop Sports Phys Ther 1998;28:192-202.

10. Gomoll AH, Minas T. The quality of healing: Articular cartilage. Wound Repair Regen 2014;22:30-38.

11. McAdams TR, Mithoefer K, Scopp JM, Mandelbaum BR. Articular cartilage injury in athletes. Cartilage 2010;1: 165-179.

12. Steinwachs M, Engebretsen L, Brophy R. Scientific evidence base for cartilage injury and repair in the athlete. Cartilage 2012;3:11S-17S.

13. Pánics G, Hangody LR, Baló E, Vásárhelyi G, Gál T, Hangody L. Osteochondral autograft and mosaicplasty in the football (soccer) athlete. Cartilage 2012;3:25S-30S.

14. Peterson L, Junge A, Chomiak J, Graf-Baumann T, Dvorak J. Incidence of football injuries and complaints in different age groups and skill-level groups. Am J Sports Med 2000;28:S51-S57.

15. Messner K, Maletius W. The long-term prognosis for severe damage to weight-bearing cartilage in the knee: A 14-year clinical and radiographic follow-up in 28 young athletes. Acta Orthop 1996;67:165-168.

16. Piasecki DP, Spindler KP, Warren TA, Andrish JT, Parker RD. Intraarticular injuries associated with anterior cruciate ligament tear: Findings at ligament reconstruction in high school and recreational athletes. An analysis of sex-based differences. Am J Sports Med 2003;31: 601-605.

17. Drawer S, Fuller C. Propensity for osteoarthritis and lower limb joint pain in retired professional soccer players. $\mathrm{Br}$ J Sports Med 2001;35:402-408.

18. Engström B, Forssblad M, Johansson C, Tornkvist H. Does a major knee injury definitely sideline an elite soccer player? Am J Sports Med 1990;18:101-105.

19. Kujala UM, Kettunen J, Paananen H, et al. Knee osteoarthritis in former runners, soccer players, weight lifters, and shooters. Arthritis Rheum 1995;38:539-546.

20. Arendt E, Dick R. Knee injury patterns among men and women in collegiate basketball and soccer NCAA data and review of literature. Am J Sports Med 1995;23: 694-701.

21. Roos H. Are there long-term sequelae from soccer? Clin Sports Med 1998;17:819-831.

22. Felson DT, Lawrence RC, Dieppe PA, et al. Osteoarthritis: New insights. Part 1: The disease and its risk factors. Ann Intern Med 2000;133:635-646.

23. Heir S, Nerhus TK, Røtterud JH, et al. Focal cartilage defects in the knee impair quality of life as much as severe osteoarthritis a comparison of knee injury and osteoarthritis outcome Score in 4 patient categories scheduled for knee surgery. Am J Sports Med 2010;38:231-237.

24. Noyes FR, Bassett R, Grood E, Butler D. Arthroscopy in acute traumatic hemarthrosis of the knee. Incidence of anterior cruciate tears and other injuries. J Bone Joint Surg Am 1980;62:687-695.
25. Indelicato P, Bittar E. A perspective of lesions associated with ACL insufficiency of the knee. A review of 100 cases. Clin Orthop Relat Res 1985;198:77-80.

26. Shelbourne KD, Jari S, Gray T. Outcome of untreated traumatic articular cartilage defects of the knee. J Bone Joint Surg Am 2003;85:8-16.

27. Widuchowski W, Widuchowski J, Koczy B, Szyluk K. Untreated asymptomatic deep cartilage lesions associated with anterior cruciate ligament injury results at 10- and 15-year follow-up. Am J Sports Med 2009;37:688-692.

28. Mandelbaum BR, Browne JE, Fu F, et al. Articular cartilage lesions of the knee. Am J Sports Med 1998;26:853-861.

29. Cole BJ, Pascual-Garrido C, Grumet RC. Surgical management of articular cartilage defects in the knee. J Bone Joint Surg Am 2009;91:1778-1790.

30. Brophy RH, Zeltser D, Wright RW, Flanigan D. Anterior cruciate ligament reconstruction and concomitant articular cartilage injury: Incidence and treatment. Arthroscopy 2010;26:112-120.

31. Mithoefer K, Peterson L, Saris DB, Mandelbaum BR. Evolution and current role of autologous chondrocyte implantation for treatment of articular cartilage defects in the football (soccer) player. Cartilage 2012;3:31S-36S.

32. Peterson L, Vasiliadis HS, Brittberg M, Lindahl A. Autologous chondrocyte implantation a long-term follow-up. Am J Sports Med 2010;38:1117-1124.

33. Mithoefer K, Peterson L, Mandelbaum BR, Minas T. Articular cartilage repair in soccer players with autologous chondrocyte transplantation functional outcome and return to competition. Am J Sports Med 2005;33:1639-1646.

34. Hambly K, Silvers HJ, Steinwachs M. Rehabilitation after articular cartilage repair of the knee in the football (soccer) player. Cartilage 2012;3:50S-56S.

35. Verdonk P, Dhollander A, Almqvist K, Verdonk R, Victor J. Treatment of osteochondral lesions in the knee using a cell-free scaffold. Bone Joint J 2015;97:318-323.

36. Bekkers J, de Windt TS, Brittberg M, Saris D. Cartilage repair in football (soccer) athletes what evidence leads to which treatment? A critical review of the literature. Cartilage 2012;3:43S-49S.

37. Bekkers JE, Inklaar M, Saris DB. Treatment selection in articular cartilage lesions of the knee. A systematic review. Am J Sports Med 2009;37:148S-155S.

38. Harris JD, Brophy RH, Siston RA, Flanigan DC. Treatment of chondral defects in the athlete's knee. Arthroscopy 2010;26:841-852.

39. Liberati A, Altman DG, Tetzlaff J, et al. The PRISMA statement for reporting systematic reviews and meta-analyses of studies that evaluate health care interventions: Explanation and elaboration. Ann Intern Med 2009;151:W65-W94.

40. Coleman B, Khan K, Maffulli N, Cook J, Wark J. Studies of surgical outcome after patellar tendinopathy: Clinical significance of methodological deficiencies and guidelines for future studies. Scand J Med Sci Sports 2000;10:2-11.

41. Poehling GG, Jenkins CB. Levels of evidence and your therapeutic study: What's the difference with cohorts, controls, and cases? Arthroscopy 2004;20:563.

42. Wright JG, Swiontkowski MF, Heckman JD. Introducing levels of evidence to the journal. J Bone Joint Surg Am 2003;85:1-3. 
43. Jakobsen RB, Engebretsen L, Slauterbeck JR. An analysis of the quality of cartilage repair studies. J Bone Joint Surg Am 2005;87:2232-2239.

44. den Hamer A, Heusinkveld M, Traa W, et al. Current techniques for management of transverse displaced olecranon fractures. Muscles Ligaments Tendons J 2015;5:129.

45. Kon E, Filardo G, Berruto M, et al. Articular cartilage treatment in high-level male soccer players a prospective comparative study of arthroscopic second-generation autologous chondrocyte implantation versus microfracture. Am J Sports Med 2011;39:2549-2557.

46. Beyzadeoglu T, Onal A, Ivkovic A. Matrix-induced autologous chondrocyte implantation for a large chondral defect in a professional football player: A case report. J Med Case Rep 2012;28:1.

47. Harada H, Kobayashi M. Case report of osteochondral autogenous transfer for spontaneous osteonecrosis of the medial femoral condyle of the knee in an elderly soccer player. Japan J Clin Sports Med 2012;20:586-589.

48. Mina NZ, Cuéllar EC, Chaparro IM. Experiencia en el tratamiento de lesiones condrales de rodilla en futbolistas profesionales. Revisión de 34 casos. Acta Ortopedica Mexicana 2007;21:267-273.

49. Mithöfer K, Minas T, Peterson L, Yeon H, Micheli LJ. Functional outcome of knee articular cartilage repair in adolescent athletes. Am J Sports Med 2005;33:1 147-1153.

50. Riyami M, Rolf C. Evaluation of microfracture of traumatic chondral injuries to the knee in professional football and rugby players. J Orthop Surg Res 2009;4:13.

51. Gudas R, Kalesinskas RJ, Kimtys V, et al. A prospective randomized clinical study of mosaic osteochondral autologous transplantation versus microfracture for the treatment of osteochondral defects in the knee joint in young athletes. Arthroscopy 2005;21:1066-1075.

52. Gudas R, Stankevičius E, Monastyreckienė E, Pranys D, Kalesinskas RJ. Osteochondral autologous transplantation versus microfracture for the treatment of articular cartilage defects in the knee joint in athletes. Knee Surg Sports Traumatol Arthrosc 2006; 14:834-842.

53. Gobbi A, Nunag P, Malinowski K. Treatment of full thickness chondral lesions of the knee with microfracture in a group of athletes. Knee Surg Sports Traumatol Arthrosc 2005;13:213-221.

54. Mithoefer K, Williams RJ, Warren RF, Wickiewicz TL, Marx RG. High-impact athletics after knee articular cartilage repair. A prospective evaluation of the microfracture technique. Am J Sports Med 2006;34:1413-1418.

55. Hangody L, Dobos J, Baló E, Pánics G, Hangody LR, Berkes I. Clinical experiences with autologous osteochondral mosaicplasty in an athletic population. A 17-year prospective multicenter study. Am J Sports Med 2010;38:1125-1133.

56. Kaplan LD, Schurhoff MR, Selesnick H, Thorpe M, Uribe JW. Magnetic resonance imaging of the knee in asymptomatic professional basketball players. Arthroscopy 2005;21:557-561.

57. Kong RW, Zelozny A. Abnormal findings on knee magnetic resonance imaging in asymptomatic NBA players. J Knee Surg 2008;2:27-33.

58. Marcacci M, Kon E, Zaffagnini S, et al. Multiple osteochondral arthroscopic grafting (mosaicplasty) for cartilage defects of the knee: Prospective study results at 2-year follow-up. Arthroscopy 2005;21:462-470.

59. Blevins FT, Rodrigo JJ, Silliman J. Treatment of articular cartilage defects in athletes: An analysis of functional outcome and lesion appearance. Orthopedics 1998;21:761.

60. Minas T, Gomoll AH, Rosenberger R, Royce RO, Bryant T. Increased failure rate of autologous chondrocyte implantation after previous treatment with marrow stimulation techniques. Am J Sports Med 2009;37:902-908.

61. Smith GD, Taylor J, Almqvist KF, et al. Arthroscopic assessment of cartilage repair: A validation study of 2 scoring systems. Arthroscopy 2005;21:1462-1467.

62. Brittberg M, Lindahl A, Nilsson A, Ohlsson C, Isaksson O, Peterson L. Treatment of deep cartilage defects in the knee with autologous chondrocyte transplantation. $N$ Engl J Med 1994;331:889-895.

63. Irrgang JJ, Anderson AF, Boland AL, et al. Development and validation of the international knee documentation committee subjective knee form. Am J Sports Med 2001;29: 600-613.

64. Espregueira-Mendes J, Pereira H, Sevivas N, et al. Osteochondral transplantation using autografts from the upper tibio-fibular joint for the treatment of knee cartilage lesions. Knee Surg Sports Traumatol Arthrosc 2012;20: 1136-1142.

65. Frisbie DD, Oxford JT, Southwood L, et al. Early events in cartilage repair after subchondral bone microfracture. Clin Orthop Relat Res 2003;407:215-227.

66. Nehrer S, Spector M, Minas T. Histologic analysis of tissue after failed cartilage repair procedures. Clin Orthop Relat Res 1999;365:149-162.

67. Jakob RP, Franz T, Gautier E, Mainil-Varlet P. Autologous osteochondral grafting in the knee: Indication, results, and reflections. Clin Orthop Relat Res 2002;401: $170-184$.

68. Hangody L, Füles P. Autologous osteochondral mosaicplasty for the treatment of full-thickness defects of weight-bearing joints. J Bone Joint Surg Am 2003;85: 25-32.

69. Bentley G, Biant L, Carrington R, et al. A prospective, randomised comparison of autologous chondrocyte implantation versus mosaicplasty for osteochondral defects in the knee. J Bone Joint Surg Br 2003;85:223-230.

70. Della Villa S, Kon E, Filardo G, et al. Does intensive rehabilitation permit early return to sport without compromising the clinical outcome after arthroscopic autologous chondrocyte implantation in highly competitive athletes? Am J Sports Med 2010;38:68-77.

71. Ebert J, Robertson W, Lloyd DG, Zheng M, Wood D, Ackland T. Traditional vs accelerated approaches to post-operative rehabilitation following matrix-induced autologous chondrocyte implantation (MACI): Comparison of clinical, biomechanical and radiographic outcomes. Osteoarthritis Cartilage 2008;16:1131-1140.

72. Alford JW, Cole BJ. Cartilage restoration: Part 1. basic science, historical perspective, patient evaluation, and treatment options. Am J Sports Med 2005;33:295-306.

73. Slynarski K, Deszczynski J. Algorithms for articular cartilage repair. Transpl Proc 2006;38:316-317.

74. Vanlauwe J, Almqvist F, Bellemans J, Huskin J-P, Verdonk R, Victor J. Repair of symptomatic cartilage 
lesions of the knee: The place of autologous chondrocyte implantation. Acta Orthop Belg 2007;73:145-158.

75. Mithoefer K, Saris DB, Farr J, et al. Guidelines for the design and conduct of clinical studies in knee articular cartilage repair International Cartilage Repair Society recommendations based on current scientific evidence and standards of clinical care. Cartilage 2011;2: 100-121. 